\title{
Sustainable Approach for Poverty Reduction in Rwanda
}

\author{
Kahigana Innocent \\ Department of Travel and Tourism Management, University of Tourism Technology and Business Studies (UTB), Kigali City, Rwanda \\ Email address: \\ gahicent@yahoo.com \\ To cite this article: \\ Kahigana Innocent. Sustainable Approach for Poverty Reduction in Rwanda. Journal of Investment and Management. \\ Vol. 7, No. 1, 2018, pp. 19-24. doi: 10.11648/j.jim.20180701.13
}

Received: February 12, 2018; Accepted: March 1, 2018; Published: March 20, 2018

\begin{abstract}
The notion of smart solution is globally perceived as the process of enduring values in terms of its characteristics and meanings that are economically viable, environmentally friendly, socially acceptable, and humanly beneficial. The social, economic, environmental, and human sustainability is the best integrated approach in the poverty reduction. Though poverty remains global challenge, there is a need for sustainable approach reflected in the requisite capabilities, partnership features, and indispensible capitals for its reduction. In Rwanda, several challenges still retard all initiatives to fight poverty. These include shortage of household capabilities and indispensable as well as more private sector centered partnership for poverty reduction. But an integrated approach which treats environmental, economic, social, and technical aspects as one component is crucial for shared responsibilities of different parties in poverty reduction.
\end{abstract}

Keywords: Sustainability, Poverty, Indispensable Capital, Partnership

\section{Introduction}

The notion of smart solution which refers to applicable technologies and human intelligence, has gained global attention with more focus on sustainable approach to undertake (Urry and Grieco, 2011). The more considered sustainble approach was described by Haghightat and Kim (2009) as an advanced intergtred approach that motivates experts from different disciples to join expertise and work together under the guidence of specfic purpose. It was also regareded by Bueren et al (2012) for its potential to shift the priority among the particular targets to more subtle interaction. Likewise, Kodmany and Ali (2013) noted that sustainable approach consider the overall move towards achieving balanced multiple environmental, social, and economic issues, rather than just incorporating sustainable features in the very action taken. The fact is that sustainable approach has as well been globally perceived in terms of its characteristics and meanings as the process of enduring solutions that are economically viable, environmentally friendly, socially acceptable, and humanly beneficial (Walker, 2006). The economically viable solution involves maintaining the total natural stock together with manufactured capital by consuming less than the valueadded. The environmentally friendly solution focuses on maintenance of natural capital as source of economic inputs and as sink for wastes. The socially acceptable solution involves maintenance of the social capital such as community cohesion, compassion, tolerance, love, forbearance, fellowship, discipline, ethics as well as shared values. The humanly beneficial encompasses maintenance of human capital including education, knowledge, skills, health, leadership, and access to services (Gough and Scott, 2003).The social, economic, environmental and human sustainability approaches were valued by Øyen and Cimadamore (2002) the best practices in the poverty reduction. Poverty reduction is arithmetically related to the economic growth, income distribution and distribution changes. The changes in the level of poverty are associated with the changes in per capita incomes and distribution of such incomes (Khan, 2009). Poverty reduction is all about working round the year not to just be reduced to one day jubilance (Singh, et al. 2009). The poverty reduction becomes meaningful when it is sustainable rather than transitory (Banerjee and Chakrabarti, 2013). The meaningful poverty reduction was overriding goal among the global development activities under the United Nations Millennium Development Goals (Mowforth and Munt, 2009). It has remained number one among the marshaled United Nations Sustainable Development Goals (UN, 2015).However, United Nations Millennium Development Goal relating to the 
reduction of extreme poverty seemed unevenly achieved across various countries where an estimated $15.5 \%$ of the world populations still suffer from hunger (Fehling et al, 2013). Part of the world where extreme poverty reduction seemed unevenly achieved, the United Nations Economic and Social Commission for Asia and the Pacific (2009) attributed the cause to the deviation of some countries from such global goal. The OECD (2001) forethought key causes for such deviation as endless local government mobilizing, institutional capacity building, forging public-private partnerships, strengthening ownership and accountability. It is also more challenging to sustain poverty reduction approach once the funding together with human and technological supports are withdrawn (Pound, et al, 2013).

Despite the unevenly achieved extreme poverty reduction around the world the by the UN Millennium Development Goal, again ending poverty in all its forms worldwide by 2030 is what the newly adopted number one UN Sustainable Development Goal is all about; which uncertainty principle developed in 1927 by German physicist Werner Heisenberg asserts a fundamental limit to the precision of such universal target. Heisenberg's uncertainty principle states that the more the position of an aspect is not precisely determined the less precise is its momentum (Francis, 2017). This less precise momentum is also claimed byHeisenberg's stipulations about the new way of thinking about critical physical problems and new insights about the workings of nature (Mehra and Rechenberg, 2001).The new way of thinking about critical physical problems is related to the real world in which humankind live (Bisplinghoff, 2002). Whilst the workings of nature are the composition of groundwork, the carrier, and the promoter of the human cognitive process (Tymieniecka, 1987). Likewise, the new UN poverty reduction agenda is pure generic for member countries to contextualize it into their respective national strategies. This generic approach detaches UN member countries from global sustainable solution for poverty reduction and leaves them into their solitary challenges of applicability, implementability, and transformational (Osbornet al, 2015). Other challenges are associated with accountability, trade-offs, and stakeholder involvement (Patterson, 2015).The such UN must do it, though generic to many parts of the world, poverty reduction approach has prompted several countries such as Rwanda to devise poverty reduction strategy amidst unmet energy demand, skills deficit, land shortage, low direct foreign investment, limited availability of long-term savings and credit, increasing population density, and weak private sector feared to jeopardize her economic transformation (GoR, 2013). In this case, a scientific study was necessary to analyse possibilities of sustainable solution for poverty reduction in Rwanda, focusing on the following research questions;

i. What are requisite capabilities for poverty reduction?

ii. What are partnership features for poverty reduction?

iii. What are indispensable capitals for poverty reduction?

Literature Review

The review of literature, to have abroad overview about possibilities of sustainable solution for poverty reduction in Rwanda, adopted theoretical framework that provides two types of explanations. The first explanation is about the relationship of variables under study, whereas the second explanation is about the anticipation of a particular set of outcomes (Fitzpatrick and Wallace, 2006). The study adopted a triad model illustrated below, which was derived from the three theories that prescribe public strategy formulation process.

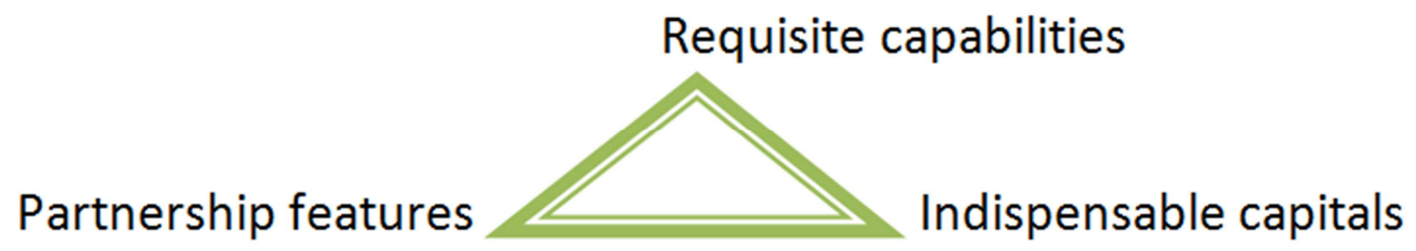

Figure 1. Indicates the triad model applied in the study.

The study adopted theoretical framework to check, qualify, and elaborate the boundaries of considered model with variables of requisite capabilities as well as partnership features and indispensable capitals. This theoretical framework was helpful to develop and refine the applied theories in this study which included natural person theory, capital theory as well as capability theory. The natural person theory regards partnership as necessary approach to reduce the sources of degree of efficiency individuals and firms maintain under conditions of imperfect competition and allow more competitiveness (Casson, 2003). The capital theory prescribes the strategic justification of customer relationships noting that profit resides on modes of capital applications not reflected in the actual market prices (Kleinaltenkamp and Ehret, 2006). The capability theory explains the production of wellbeing and provides guidance on the most appropriate methods to measure wellbeing. The theory suggests that the wellbeing can understood and evaluated if the focus is on functionings and capabilities. Functionings are all about beings and doings that a person performs while capabilities is all about the role of agency in the selection of beings and doings a person performs in line with his/her values. It provides more direct analysis of vulnerability and poverty as it focuses on wellbeing as contrary to consumption, income, and assets (Shepherd and Brunt, 2013).

The requisite capabilities for poverty reduction

The requisite capabilities include core human capabilities and financial capabilities. The human capabilities encompass thinking, learning and communicating (Agon, 2016).Likewise, there are seven human related general capabilities that encompass the knowledge, skills, behaviors 
and dispositions that can be developed in all learning areas. They include literacy, numeracy, ICT, critical and creative thinking, personal and social, ethical understanding, intercultural understanding capabilities. There is literacy capability which focuses on presentation and valuation of data as well as evidence-based arguments such as reasoning. The numeracy capability is especially evident in the science inquiry skills strand. The key aspects here include the measurements as well as the representation of numerical data and identifying partners. The ICT capability helps people to generate and test some of their models and predictions. The critical and creative thinking capability enable people to examine the way they interpret the world and how their knowledge and opinions are shaped by those around them. The personal and social capability enables people to make more informed choices about such day-to-day matters as their health and nutrition as well as environmental actions. The ethical understanding capability implies people's behaving responsibly towards themselves, others and the animate and inanimate world around them. The intercultural understanding capability is all about learning the contribution of range of cultures and their perspectives to the development of scientific knowledge as well as its applications (Preston and Skamp, 2015). The financial capability takes into account the impact of surrounding environment on people's ability to achieve positive outcomes. It combines a person's knowledge, skills, and financial behavour with a person's access to beneficial financial products, services in addition to public polices (Aprea, 2016). Building requisite capabilities through education is what MINECOFIN (2013) emphasized to ensure that different households in Rwanda are able to strengthen their livelihoods.

\section{The partnership features for poverty reduction}

Ideally, partnership should have number of the features that are necessary for its success. They include the consultation with the community in which the partnership is situated. It focuses more on what are the needs of the area residents. The consultation partnership is where public authorities consult other actors in order to facilitate the implementation of their policies. This leads to the signing of the agreements between the government and the different stakeholders (Lind, 2004). The other partnership feature is the community involvement in the broader network that the partnership should establish over time to ensure that people know what is happening. The community involvement partnership is recognized as an important aspiration in order to build in better local knowledge concerning needs, greater potential for the joining up of services, and enhance motivation of front-line staff that can lead to innovation in the service delivery (McCarthy, 2016). There is partnership feature of communication at broader level, subcommittee level and at ground level. Communication partnership feature helps to design development projects responsive to the needs of the poor and public-at-large (Calabrese, 2008). The other partnership feature is the commitment by all of those who are involved in the many layers of the partnership structure. Gaining commitment for partnership relies on that party fully understanding what is being asked and what such partnership might involve (Steward, 1999). There is also partnership feature of control of local decision-making about resources for the area. The most important of all, good partnerships will ensure a strong inputs from and involvement by the people who actually know or experience the realities of poverty (Craig, 1995). The development of sustainable solution for poverty reduction illustrates importance of public-private partnership in Rwanda represented by sectorial working group, which World Bank (2010) said to be serving as forum for debate, collaboration along with information sharing.

The indispensable capitals for poverty reduction

The indispensable capitals are up today including natural, physical, human, financial, and social capital. The natural capital is composed of land, water, and trees that yield products utilized by human population for their survival. The physical capital encompasses tools, machines, and land improvements such as terraces or irrigation canals brought into existence by economic production process. Human capital refers to health status and educational level of individuals and populations. Financial capital includes stocks of cash that can be accessed in order to procure goods or services that might be useful for consumption or production. Social capital refers to the social networks and associations in which people participate and from which they can drive support that contributes to their livelihoods (Abdalla, 2013). The societies or areas which possess large amount of indispensable capitals are generally more prosperous than those that lack them to enable production. If indispensable capitals are available it will be possible to buy the other factors necessary for production spearheaded by the government of every country or state (Marshall, 2000). The role of government is essential for capital increments or wealth-creation and development to lay the foundations for a country like Rwanda to be competitive in the modern international economy (IBP, 2013).

\section{Methodology}

The study, which was qualitative in nature, adopted desk research approach that provided alternative procedure for gathering the necessary data (Kent, 1993). The partial interviews were also conducted among private sector members and local government officials to authenticate relevance of literatures used. Their responses were further incorporated into secondary data collected through extensive review of literatures on Rwanda's requisite capabilities, partnership features, and indispensible capitals. The study, which was as well analytical, dealt with questions that generated data about sustainable solution for poverty reduction in Rwanda. An analytical study according to Cohen (2016) first draws attention to unknown and proceeds to the known by evaluating the facts and information relative to the problem being studied. 


\section{Results}

\subsection{Poverty Alleviation with Requisite Capabilities}

In Rwanda, some poverty reduction requisite capabilities for instance the ICT access appear nearly identical to the mobile phone access; so when households referred to ICTs, it is highly likely that they were referring to mobile phone access. The households are always faced with difficult spending decisions on the use of mobile phones mostly in the response to shocks, including the food and fuel price increase (Adera, 2014). Likewise, MINALOC (2013) highlighted limited human capacities as still a challenge mainly in planning, monitoring and evaluation at local community level. MINALOC also pointed out lack of financial literacy as well as needed technical (industrial and off-farm) skills and entrepreneurial ambitions at household levels mainly in the rural areas.

\subsection{Promoting Partnership for Poverty Reduction}

The Rwanda's current partnership features considering the public-private, show potential for poverty reduction and economic development. The government of Rwanda has in principle given the operation of public-private partnership approach ago ahead by giving the responsibility to Rwanda Development Board (RDB). There is also an enacted law, which Chamber of Deputies (2015) noted that it applies to the public-private partnership arrangements such as the management contract, whereby a contracting authority awards a partner the right to manage and perform a specific service with respect to an infrastructure facility or other asset for an agreed time period. This law aims at filling the gaps within the current state of public-private partnership in Rwanda, which Nuwagaba (2013) claimed that it indicates existence of concessions given to the investors in some important sectors for the country's economic growth. Nuwagaba's concern was also raised by Kahigana(2016) who highlighted an example of concession policy in tourism sector that loads investors with more responsibilities of developing and managing touristic facilities in the protected areas; whilst the partnered government agency monitor the activities to ensure compliance with the concession agreement. The Ministry of Trade and Industry (2013) noted that concessionaires are brought on board due to budgetary and capacity constraints faced by public sector, which private sector is expected to given a hand in addressing it; though Brebbia (2010) claimed that such initiative reduce the opportunities for income generation of local communities in such sectors or around selected sites.

\subsection{Fighting Poverty with Indispensable Capitals}

The indispensable capitals of Rwanda which include natural, physical, human, financial, and social features are characterized by critical challenges. Likewise, the current slow pace and shortfalls of development actors to address social capital threats such as the increasing population pressure, and degradation of necessary resources still remains a key challenge (Grootaert, 2003). Additionally, MINECOFIN (2013) hihglighted different threats to financial capital of Rwanda as the country's inability to mobilize long term stable financings, low savings culture, limited access to banking products and services in rural areas, low households incomes, small and underdeveloped capital market, concentration of micro finance institutions in the urban and major cities. The human capital threats include shortage of graduate professionals in the economic development and poverty reduction thematic areas (RDB, 2012). The key physical capital threats stated by MINECOFIN (2013) include among others lack of access to the coast, shortage of world class physical infrastructure, and modern agriculture practices.

\section{Discussion}

The lack requisite capabilities such as human capabilities which have key role to play in stabilising assets for livelihood transformation mainly in the poorest households of Rwanda make it difficult to have steady and quick poverty reduction. It is also noted that lack of such capabilities has continued to make agriculture main source of survival among rural households; however, available land for agriculture success is still impossible due to pressure by increasing population density. Furthermore, limitations of land, skills, and infrastructure which still hinder the rural development ambitions. The other highlighted obstacles are the nature of rural poverty and budgetary implications associated with cash transfers still challenged by the public programmes and private sector job opportunities to ensure that households are able to strengthen their livelihoods. Likewise, investment in whatever facilitates income-generating activities on and offfarm remains highly demanding feature for providing these opportunities. Additionally, limited financial access and education related challenges continue to deny people with the knowledge and skills needed to quickly graduate from poverty. The public-private partnership approach that have been given ago ahead in Rwanda focuses more on the procurement method the government is set to use to deliver public services and infrastructure putting consideration prioritized sectors for economic development and poverty reduction. It is therefore important to notice that the government (public actor) made deliberate choice of concession model to recoil from risks as well as expertise and financial constraints and let the private sectors take the lead. However, the private sector-led concession tends to be selective when it is time to innovate and respond to changes in consumer demands; also undervalues the needs of local communities concerned in the areas or sectors selected for economic development. It seems that both government and concessioners are still to encounter difficulties to cooperate in private sector-led development in such areas. Though, private investors are expected to invest more (expertise and finance), but concession arrangements do not explicitly prescribe the state mechanisms to the guarantee of private investments. The other main challenging phenomenon is to 
balance social and economic development in a manner that would enable the country get her way out of poverty darkness.

\section{Conclusion}

The sustainable approach for poverty reduction is the most pertinent one. It integrates social, economic, technical, and environmental issues. Globally, sustainable approach for poverty reduction is associated with seven human and financial capabilities. It also values consultation partnership which enables public authorities to consult other actors in order to facilitate the implementation of their policies; and the indispensable capitals for poverty reduction including natural, physical, human, financial, and social capitals. However, in Rwanda, limited financial access and education related challenges continue to deny people with the knowledge and skills needed to quickly graduate from poverty. There is also private sector centered partnership which tends to be selective when it is time to innovate and respond to changes in consumer demands; also undervalues the needs of local communities concerned in the areas or sectors selected for economic development. Otherwise, an integrated approach that would bring different experts together is necessary in Rwanda and elsewhere in the world fight poverty.

\section{References}

[1] Abdalla, G. A. (2013). The influence of financial relations on sustaining rural livelihood in Sudan: reflecting the significance of social capital in the village Al Dagag, North Kordofan State. Berlin: Freie Universität.

[2] Adera, E. O. (2014). ICT Pathways to Poverty Reduction: Empirical evidence from East and Southern Africa. Ottawa: Practical Action Publishing Ltd.

[3] Agon, T. (2016). Human key condensed. Houston: Xagon Inc.

[4] Amita Singh, K. K. (2009). Governance and poverty reduction: beyond the cage of best practices. New Delhi: PHI Learning Private Limited.

[5] Anna-Teresa, T. (1987). Logos life. Boston: Kluwer Academic.

[6] Aprea, C. (2016). International handbook of financial literacy. Singapore: Springer.

[7] Banerjee, S., \& Chakrabarti, A. (2013). Development and sustainability: India in a global perspective. New York: Springer.

[8] Barry Pound, S. S. (2013). Managing natural resources for sustainable livelihoods: uniting science and participation. London: Earthscan Publications.

[9] Bisplinghoff, R. L., Wah Mar, J., \& Pian, T. H. (2002). Statics of deformable solids. New York: Dover.

[10] Brebbia CA (2010) The sustainable world, Southampton. Wessex Institute of Technology, UK.
[11] Calabrese, D. (2008). Strategic communication for privatization, public-private partnerships, and private participation in infrastructure projects. Washington: World Bank.

[12] Casson M (2003) The entrepreneur: an economic theory. Cheltenham, UK, Edward Elgar.

[13] Chamber of Deputies (2015) Deputies voted the public private partnerships law. Kigali, Parliament of Republic of Rwanda.

[14] Cohen A. William, (2016) Peter Drucker on consulting: how to apply Drucker's principles for business success, New York, LID Publishing.

[15] Craig, S. (1995). Making partnership work: a handbook on involvement in local development partnerships. Dublin: Combat Poverty Agency.

[16] Edwards, A. R. (2005). The sustainability revolution: portrait of a paradigm shift. New York: Gabriola, B.C.: New Society Publishers.

[17] Ehret, M. K. (2006). The value added by specific investments: a framework for managing relationships in the context of value networks. In M. K. Ehret, Relationship theory and business markets (pp. 65-71). Bradford: Emerald Group Publishing.

[18] Ellen M. van Bueren, H. v. (2012). Sustainable urban environments: an ecosystem approach. Paises Bajos: Springer.

[19] Fariborz Haghighat, J.-J. K. (2009). Sustainable built environment. Oxford: Eolss Publishers.

[20] Fitzpatrick J. Joyce and Wallace Meredith, (2006). Encyclopedia of nursing research, 2nd ed. New York, USA: Springer Pub.

[21] Francis, C. (2017). Light after dark II: the large and the small. Leicestershire: Troubador Publishing Ltd.

[22] Gough, S., \& Scott, W. (2003). Sustainable development and learning: framing the issues. London: Routledge Flamer.

[23] Grootaert, C. (2003). The role of social capital in development: an empirical assessment. Cambridge: Cambridge Univ. Press.

[24] Hon, B. (2003). Design and manufacture for sustainable development 2003. London: Professional Engineering Publishing Limited.

[25] IBP. (2013). Rwanda Business Law Handbook: Strategic Information and Laws. Washington: International Business Publications.

[26] Kahigana, I. (2016). Effectual Partnership for Tourism Sector Transformation in Rwanda. Journal of Tourism \& Hospitality, $1-5$.

[27] Kent. A. Raymond, (1993). Marketing research in action.Routledge, New York, USA.

[28] Khan, M. H. (2009). Governance, growth and poverty reduction. New York: UNDESA.

[29] Kheir Al-Kodmany, M. M. (2013). The Future of the City: Tall Buildings and Urban Design. Southampton: WIT Press.

[30] Lind, J. (2004). Labour and employment regulation in Europe. Bruxelles: Lang. 
[31] Marshall, T. (2000). Principles of Business for CXC. surrey: Nelson.

[32] Martin Charter, U. T. (2001). Sustainable solutions: developing products and services for the future. Sheffield: Greenleaf Publishing Limited.

[33] Maya Fehling, B. D. (2013). Limitations of the Millennium Development Goals: a literature review. An International Journal for Research, Policy and Practice, 1109-1122.

[34] McCarthy, J. (2016). Partnership, Collaborative Planning and Urban Regeneration. Routledge: New York.

[35] Mehra, J., \& Rechenberg, H. ( 2001). The historical development of quantum theory. New York: Springer.

[36] MINECOFIN. (2013). Economic Development and Poverty Reduction Strategy II 2013-2018. Kigali: Great Lakes Communications Company.

[37] MINECOFIN. (2013). Rwanda financial sector strategy. Kigali: MINECOFIN.

[38] MINALOC (2013). National strategy for community development and local economic development. Kigali, MINALOC.

[39] Ministry of Trade and Industry (2013) Rwanda protected areas concessions management policy. Kigali, MINICOM.

[40] Mowforth, M., \& Munt, I. (2009). Tourism and sustainability: development, globalisation and new tourism in the third world. London: Routledge.

[41] Nuwagaba A (2013) Public Private Partnerships (PPPs) and their effect on services delivery in Rwanda. International Journal of Economics, Finance and Management 2: 5.

[42] OECD. (2001). Poverty reduction. Paris: OECD.

[43] Osborn, D., Cutter, A., \& Ullah, F. (2015). Universal sustainable dvelopment; understanding the transformational challenge for developed countries. New York: UN.

[44] Øyen, E., \& Cimadamore, A. D. (2002). Best practices in poverty reduction: an analytical framework. New York: Zed Books Ltd.
[45] Pacific, U. N. (2009). Review of developments in transport in Asia and the Pacific 2007: data and trends. Bangkok: ESCAP.

[46] Patterson, J. (2015, August 4). The 3 challenges facing the UN's Sustainable Development Goals. Retrieved Febuary 25, 2017, from World Economic Forum: https://www.weforum.org

[47] Paulina Golinska, M. H. (2012). Sustainable transport: new trends and business practices. Berlin: Springer.

[48] Preston, C., \& Skamp, K. (2015). Teaching primary science constructively. South Melbourne: Victoria Cengage Learning.

[49] RDB. (2012). National skills survey report. Kigali: RDB.

[50] Rwanda, G. o. (2013). Economic Development and Poverty Reduction Strategy II. Kigali: Ministry of Finance and Economic Planning.

[51] Shepherd, A., \& Brunt, J. (2013). Chronic poverty: concepts, causes and policy. Basingstoke: Palgrave Macmillan.

[52] Steward, C. (1999). Developing strategic partnerships: how to leverage more business from major customers. Aldershot: Gower Publishing Limited.

[53] Tolba, M. K. (2001). Our fragile world: challenges and opportunities for sustainable development. Oxford: EOLSS Publishers.

[54] Tymieniecka, A. T. (1987). Impetus and equipoise in the lifestrategies of Reason: logos and life. Boston: Kluwer Academic.

[55] UN. (2015). Resolution adopted by the General Assembly on 25 Se. New York: UN.

[56] Urry, J., \& Grieco, M. (2011). Mobilities: new perspectives on transport and society. Surrey: Ashgate Publishing.

[57] Walker, S. (2006). Sustainable by design: explorations in theory and practice. London: Earthscan.

[58] World B (2010) Innovation policy: a guide for developing countries. Washington DC, World Bank. 